\title{
Discontinuities Within Continuities: Solidarity, (Im-)Mobility and Migration Between Refugee Crisis and COVID-19 Crisis
}

\author{
Eveline ODERMATT ${ }^{1}$ \\ University of Fribourg
}

\begin{abstract}
Since the peak of the so-called refugee crisis in 2015, much has been written on the topic of solidarity towards migrants. However, the perspective of migrants on the issue of solidarity and their practices of solidarity has been addressed less. This article aims to outline solidarity in the context of migration in more detail. Firstly, I will outline how solidarity played out towards migrants during the refugee crisis, and I will sketch how migrants engage in cross-border solidarity, having left their sending countries and families behind. Secondly, I will illustrate continuities and discontinuities between the refugee crisis and the COVID-19 crisis with regards to migration policies implemented during these crises. Hereinafter, I will highlight the impacts of these migration measures on the migrants' capacity to manifest solidarity as well as on forms of solidarity towards migrants. The main argument is that bridging these two crises the refugee crisis and the COVID-19 crisis - can deepen our understanding of the interplay between migration policies put in place and forms of solidarity among migrants or towards migrants. Hence, the article aims to contribute to the broader discussion on the diverse ways of how crises and crises discourses affect migration policies and consequently the migrants.
\end{abstract}

Keywords: solidarity, migration, transnational solidarity, refugee crisis, COVID-19 crisis

\section{Introduction}

Around the peak of the so-called refugee crisis in 2015, restrictive migration measures were implemented across Europe, such as the restrictions to the entry of low-skilled migrants and asy-

${ }^{1}$ Eveline Odermatt, $\mathrm{PhD}$, is a researcher and lecturer in the Department of Sociology, Social Policy, and Global Development at the University of Fribourg (eveline.odermatt@unifr.ch).

DOI: http://dx.doi.org/10.18753/2297-8224-173 
lum seekers and the increase in return and deportation. Many of these migration policies outlasted the emergency of the refugee crisis and are now intensified in the discourse on the COVID-19 crisis. In the current time of immobility, neo-nationalism and rising unemployment rates, once again, migrants at large are at risk of becoming one of the first targets of restrictive measures (Vertovec 2020a).

Crises question certainties and imply change, and they are disruptions of what is considered normal (Bhabha 2018). On this understanding, I discuss how crises and crisis discourses have changed state migration regimes and activities of civil society in the field of migration in recent years. It is well-known that individuals in general experience the present crisis - in this case the COVID-19 crisis - as the worst crisis. This might explain why both crises, the refugee crisis and the COVID-19 crisis, and their respective discourses have often been kept apart in the broader literature. Thus, this article aims to bridge discussions surrounding solidarity practices of migrants and manifestations of solidarities towards migrants during the refugee crisis and the COVID-19 crisis.

It is worth mentioning that the concept of solidarity is not without its problems. It has a history worth exploring, but that would go beyond the scope of this article. In short, the three main strands of approaching the concept of solidarity can be divided into, first, Emile Durkheim's functionalist account of solidarity as a means of social cohesion and order between individuals and the society as a whole. Secondly, we can consider the work of Karl Marx, Max Weber and Georg Simmel that deal with solidarity from a perspective of conflict theory as a source of collective action for different groups in competition with each other (Crow 2001). Thirdly, there are philosophical ways of examining solidarity. That is to say that there is something within each of us - our essential humanity - which resonates to the presence of the same thing in other human beings (Crow 2001).

In the first section of this paper, drawing on my own data, I will briefly introduce various transnational solidarity engagements carried out by migrants. I then sketch some aspects of migrant solidarity practices, which I argue have often been left out in the broader literature on migrants as transnational solidarity actors. This is followed by some examples of global migration restrictions and their negative impacts on migrants' giving capacity towards their home countries and families left behind.

In the second section I reflect on the current coronavirus crisis that has brought to the fore the manifold ambivalent meanings of mobility and solidarity. In spring 2020, mobility and migration were severely challenged by COVID-19. Restrictions of human mobility at a local, national and international level such as lockdowns and border closures were introduced. This has especially affected international migrants, who were finding themselves stranded in their countries of origin, in their destination countries or in transit countries. According to the IOM (2020), in the summer of 2020, restrictions imposed to combat the COVID-19 pandemic prevented more than 2.75 million migrants from returning home. I analyse how COVID-19 impacts upon migrants' capacity to become solidarity actors and how COVID-19 shapes forms of solidarities towards migrants. Furthermore, I elaborate similarities and differences in dealing with migration in the context of the refugee crisis and the present COVID-19 crisis. This leads 
us to the main two questions of this article, namely: Where are continuities with regards to solidarity practices towards migrants and among migrants in the two crises? Where can we find discontinuities and new forms of solidarity?

The concluding paragraph discusses possible scenarios of solidarity and transnational mobility during and after the COVID-19 crisis. At a time when one crisis discourse replaces another, the question arises whether the two crises discussed here can be solved with solidarity. I then consider how the currently immobile society can reorganise itself to find a way out of these crises, and I outline necessary further steps in migration policy making post the COVID-19 era by suggesting a more global approach to migration policy making.

\section{Solidarity Towards Migrants and Migrants as Actors of (Transnational) Solidarity}

Undoubtedly, the rights and entitlement of refugees and migrant groups are among the most contested political issues of our times. In particular, the integration of refugees ${ }^{2}$ is at the centre of political debates across Europe. Without going into details, there have been numerous debates among scholars whether the refugee crisis indeed was a real crisis in terms of numbers or not (see, e.g., Collyer and King 2016; Crawley 2016). Some authors proclaimed that the refugee crisis was most of all a crisis of state legitimacy; a dispute over immigration policy in the European Union that reflects deeper conflicts between two conceptions of democracy: a liberal one that pushes towards fairly open borders, and a protectionist one that pushes towards national closure (Bauböck 2020). Other scholars stressed that the crisis emerged because transnational solidarity has simply failed in the refugee system, despite the fact that solidarity per se is declared as one of the fundamental values in the Millennium Development Goals (MDGs) and is anchored in the Human Rights Convention (e.g., Sigona 2017).

The theoretical and empirical debates aside, around the peak of the refugee crisis in 2015, the situation in Germany was characterised by a high and sudden increase in numbers of refugees. The so-called long summer of 2015 has illustrated to what extent migration issues can polarise a society (Hager and Veit 2019). Whilst many Germans perceived the refugees as a danger, others engaged in varied ways with refugees in Germany and elsewhere in Europe (e.g., Karakayali and Kleist 2016). According to a study by the Allensbach Institute for Public Opinion Research (2018), every second German over the age of sixteen supported refugees in 2015, either by donating money or by other forms, like committing to NGO or volunteer group work. ${ }^{3}$ Interestingly, Bansak et al. (2016) have shown that during the acuteness of the refugee crisis around 2015, Europeans taking up such an engagement in general did not differentiate between political, religious, and ethnic persecutions.

Yet, relatively little has been written on the engagement of different groups of migrants living in Germany and other Western European countries in support of the incoming refugees around 2015 (for an exception, see Agustín and Jørgensen 2020), although migrants in general

\footnotetext{
${ }^{2}$ In the following, I refer to refugees when describing the incoming migrants to Europe during the so-called refugee crisis, although I am aware that refugees are migrants, too, and that migrants can become refugees on their journeys to Europe. For an overview of the discussion on the definitions of migrants and refugees, see Carling 2015 and Crawley and Skleparis 2016.

${ }^{3}$ A paradigmatic example is the large movement \#LeaveNoOneBehind, see https://seebruecke.org/kampagnen/leavenoonebehind/aktionsideen/
} 
manifest their solidarity with refugees in many ways (for an overview, see Huth 2012). Some authors rightly stress that whereas migrants' caritative solidarity forms were attracting little media coverage, migrants' political solidarity towards refugees has been neglected altogether (Van Dyk and Misbach 2016). However, the motives of migrants to engage in solidarity practices towards locals, refugees or their own migrant community were similar to the ones of local citizens. The subjectivities and identities we typically find in the literature on volunteerism and civic participation of non-migrants in Western Europe are also important factors shaping migrants' local and transnational engagements (e.g., specific personal characteristics). Another consistency with patterns of the volunteer sector of most European countries is a clear gender division between men, typically engaged in political engagement, and women who are more prone to engage in social activities (Stadelmann-Steffen 2015). Moreover, for both groups the opportunity to use one's professional skills and identities is found to play an important role in individuals' choices for a volunteer engagement (Stadelmann-Steffen 2015). Research on volunteerism has further found that it is mostly the middle class that is involved in volunteer engagement and not the most deprived population with less time and financial resources available (Beck 2011). This observation also applies to the majority of migrant communities.

A final parallel in patterns of manifestations of solidarity between citizens and migrants, consisting of shared interests and a sense of unity of groups, can be found in Jacqueline Bhabha's definition of justificatory principles driving solidarity. According to Bhabha, these are: a) proximity to the supporting person or group (cultural, spiritual, or physical); b) intensity of needs (economic, medical or political), and c) the giving capacity (material wealth, stability of democratic institutions) (2018: 33). These principles driving solidarity do not only apply to pre-existing collective identities, in the sense of a sameness, but also to other encounters. Furthermore, they refer to different organisational levels of solidarity, ranging from autonomous solidarity to the civic and the institutional level as well as to different geographical scales: from local solidarity to national and transnational forms of solidarity.

Having outlined similarities of solidarity practices among migrants and non-migrants as well as the main drivers of solidarity, in the next section I turn to migrant transnational solidarity practices and to the dominant policy approach towards these practices by drawing on my own data.

\section{Solidarity from afar: migrants as actors of transnational solidarity}

In this section, I will first discuss migrants as transnational actors of solidarity. The focus of the overview is on aspects missing in the academic and policy discourse surrounding migrant solidarity forms. I then highlight the interplay between restrictive migration measures put in place during the refugee crisis and migrants' capability to act in solidarity with their home countries and families left behind.

Migrants' individual solidarity engagements and their solidarity networks are not new phenomena. For instance, the activities of Swiss migrant associations based in London, supporting families and communities back home, dates back to 1685 (Barber 2011). Transnational solidarity with sending countries has always existed, and migrants' role in in supporting their home countries and families has been the subject of reflection for some time. Besides, the migrants' role in balancing out structural inequalities between countries of the Global North and regions 
in the Global South has long been acknowledged. Around the turn of the millennium, European state development agencies and NGOs have viewed migrants increasingly as potential drivers and actors of development in their countries of origin. As a leitmotiv of this discourse, migrants are portrayed as agents of development as a result of their associations, remittance practices or their return (e.g., IOM and MPI, 2012). The optimistic policy framing of the migration-development nexus, referring to a set of multi-faceted interdependencies between the two complex social phenomena of migration and development, has provoked a growing academic interest in migrants' transnational practices of giving and their potential to alleviate poverty in their countries of origin (Page and Mercer 2012). The terminologies used to describe migrants' individual and collective solidarity efforts in this research strand are highly multi-facetted: e.g., transnational philanthropic efforts, transnational aid-giving, collective humanitarian practices, transnational charity practices, etc.. Such transnational solidarity efforts encompass both financial transfers and other forms of remitting practices - commonly known as social remittances such as the transfer of ideas, behaviors, values, norms, knowledge, and qualifications between migrants' destination countries and places of origin (Levitt 1998).

In a previous study, I explored the Moldovan migrants' collective patterns of social and financial remittance practices (Odermatt 2017). Using a transnational bottom-up approach, I analysed their development projects by focussing on social projects such as migrants' support of local hospitals and schools or vulnerable groups in Moldova. One of the most important findings considering migrants' patterns of cross-border solidarity practices was that their aspirations to get involved in transnational aid efforts and to use their social and human capital reflects different senses of belonging and different socio-spatial units: the home country, the host country, or the transnational community of solidarity practices towards Moldova, encompassing several migrant host countries. Viewing migrants' attachments from the perspective of the places they create - the transnational migrant space of solidarity engagement - allows for an understanding of transnational social engagements with the country of origin as processes with their own dynamics, rather than reducing them to purely complementary, contradictory, or simultaneous aspects of the migrants' integration process in their host society. Thus, the processes by which these transnational development practices - be they volunteer-run or on a professional basis - can enable migrants to create a combination of belonging to different social spheres and to a multi-sited process of integration warrant more attention (Odermatt 2021).

While in the migration-development policy discourse skilled return migrants in particular are seen as potential drivers of development transition in their origin countries, the low-skilled migrants with less mobile and financial capital, are seldomly considered to belong to this category. In my opinion (Odermatt 2021), the success stories of development projects and other forms of solidarity engagement carried out by low-skilled migrants in difficult life circumstances are often more impressive than the well-documented success stories of high-skilled migrants supporting their communities and families back home (see, e.g., IOM and MPI 2012; Page and Mercer 2012). Examples of solidarity efforts carried out by low-skilled migrants are informal networks of female carers in Italy (Odermatt 2021). These women meet in their rare free time in public parks to discuss which families they would like to support in Moldova (e.g., support for medical expenses). I therefore suggest that the informal aid efforts and networks of 
low-skilled migrants in general and female migrants in particular merit more public recognition, research and policy attention.

Furthermore, both policy discourse on migrants' social remittance practices and the policy rhetoric of financial remittances prominently highlights in neat models how migrants are urged to use their financial and social remittances in productive ways and how they are supposed to show their solidarity towards their families and communities back home (IOM and MPI 2012). In each case, the prescriptive policy discourse, based on normative assumptions, does not do justice to migrants' transnational lives and the private nature of their collective financial or social investments. Therefore, it is important that we always take into account that migrants' voluntary engagements first and foremost are personal commitments, based on individual worldviews and a variety of personal, practical and emotional motivations in different social spheres (the context of the sending nations and migrant countries of residence). Additionally, the high amounts remitted by migrants to their families ${ }^{4}$ show a great solidarity towards the deprived economic and social situation of their communities of origin. This means that in many countries with high outbound migration, migrants have already taken the initiative (Odermatt 2017).

I further argue that it is crucial to better pay attention to the individual temporal dynamics implicated in migrants' understanding of transnational solidarity commitments (e.g., Vari-Lavoisier 2020). The ways in which the migrants' aspirations change over time, interweave with their life trajectories and the changing situation of their legal rights and frame their motives for transnational solidarity practices, for instance, has hardly been analysed in depth. A more timesensitive approach to migrants' motives to take up collective cross-border engagement would be fruitful for the broader discussion surrounding migrant transnational solidarity practices.

Lastly, the issue of transnational solidarities from afar has been mostly relevant to the study of international migrants and their families. In the current COVID-19 crisis and the related lockdown strategies, the issue of solidarity from a distance seems to suddenly affect everyone. The pandemic not only has a major impact on our capacity to move but also on the way we relate to others. Today, many of us are to some extent in a trans-local support relationship, given that we are separated from family and friends with whom we can only communicate via online messengers. Therefore, we can learn from research on migrant transnational solidarity practices, especially from the individual experiences of international migrants. In Ciobanu's (2020) opinion, for instance, migrants have been much better prepared for this extraordinary time because they are more familiar with the use of digital media, they have more know-how in providing support at a distance and in the creation of co-presence from afar, compared to those without a migration experience. This expertise can turn migrants into important actors of social innovation today.

\footnotetext{
${ }^{4}$ At present, globally, the sum of remittances are eight times higher than the official development assistance (ODA). In some countries, e.g., Moldova, remittances account for up to 45\% of the GDP (World Bank 2020).
} 


\section{Times have been changing: restrictive migration policies obstructing transnational solidarity practices of migrants}

On a global scale, it has been increasingly argued that scholars and policymakers have thus far not only neglected the individual temporal dynamics implicated in migrants' transnational solidarity commitments but also the temporality of migration regimes more broadly (see, e.g., Vertovec 2020b). Glick Schiller (2020: 38) maintains that even those authors who did look at the transnational dynamics of inequality structures seldomly acknowledge that the conditions for international migration in the 90 s and around the millennium were dramatically changing. According to her, it has not been sufficiently acknowledged that migrant manifestations of solidarity depend on the changing conditions and new barriers to mobility and settlement. At the beginning of the discourse on migrants as actors of solidarity towards their countries of origin, borders to Western Europe and North America were fairly porous. Even if many migrants were undocumented, legalisation was often possible through different labour schemes and other means. Scholars and policymakers assumed a continuity in different forms of migration and the porosity of borders (Glick Schiller 2020). Even after 2000 and despite the economic crisis in 2008, financial remittances and migrants' social solidarity engagement for their countries of origin were projected to continue into the future without fundamental alterations (Ratha et al. 2009). However, generalising across time seems dangerous, especially if we consider the fundamental political-economic restructuring of the factors that affect the possibilities of international migration and the potential of migrants as transnational solidarity actors nowadays. Such restructuring involved restrictive migration measures, aiming to curb international migration around the peak of the refugee crisis in 2015. These measures included the dissolution of internal EU borders, the militarisation of borders control, and an increase in border security mechanisms by the privatisation of border managements, among many others (Shachar 2020). Another prominent example of a migration management tool implemented across Europe at that time is the intensification of return enforcement. International organisations and European state development agencies have expanded their engagement in return migration schemes, such as in so-called assisted voluntary return programmes, jointly implemented with partners in migrant origin countries (e.g., GIZ 2019). Apart from these policies aimed at reducing international migration since 2015, transnational solidarity expressed by migrants has also been obstructed by policies implemented across Europe directly targeting migrants' financial and social giving capacities. Such specific policies included, among others, the taxation of remittances. In 2016 Italy, for instance, decided to charge $1.5 \%$ tax on remittances, which raised 60 million Euros in revenue (NZZ 2019). Switzerland put sanction models in place, targeting asylum seekers, migrants receiving social assistance, and social workers, to prevent emergency aids via mobile phone to families or friends living in refugee camps or in crisis-ridden home countries (Swiss State Secretariat for Migration 2019). These examples remind us of the well-known crimes of solidarities, a terminology introduced in the context of civil society engagement illustrating the penalisation of solidarity acts towards refugees. A prominent example for crimes of solidarity are boats run by volunteers and under the name of NGOs trying to save the lives of migrants on the Mediterranean Sea (see, e.g., Sigona 2017).

In sum, it is important to consider changes of migration regimes over time when analysing migrants' transnational solidarity practices. The times we live in are characterised by hostile 
migration policies involving measures of increased surveillance of borders, mass deportations, and denials of long-standing legal rights of asylum. On a global scale, these measures are threatening financial and social remittance flows towards home countries that global financial institutions and development agencies have found to be stable over a long period of time (Glick Schiller 2020). In this policy context, the level of hardship grows not only for the migrants but also for the people who depend on remittances in countries where socio-economic and political conditions are gradually worsening. In turn, this will lead to even more migration pressure and to an increase in global inequality (Yayboke 2020). In a nutshell, times have been changing and with them our approach to migration and migrants' cross-border solidarity practices must change, too.

\section{Migration and Solidarity in Times of Immobility}

In this second main section, I will sketch some post-COVID-19 crisis scenarios for the interlinkages between solidarity and migration. The outlook begins with some reflections on the continuities within the continuities of migration policies that have been implemented as a response to the two crises. I will outline some migration trends that are most likely to persists and continue to impact on our solidarity towards migrants as well as on migrants' capacity to practise solidarity in the future. As indicated in the title of this article, I will then emphasise the discontinuities or ruptures with regard to the interlinkages of migration and forms of solidarity in the two overlapping crises.

\section{Continuities within discontinuities: a glimpse into the future}

Today, international migrants represent about 3.6 per cent of the world's population (UN DESA 2020). Over the last two decades, there has been a constant increase in the number of international migrants, reaching 281 million people living outside their country of origin in 2020 . Yet, the COVID-19 crisis has significantly disrupted international mobility. According to a recent report by the UN Department of Economic and Social Affairs, the growth of international migration slowed by $27 \%$ - or 2 million migrants - due to the pandemic (UN DESA 2020). This means that thousands of migrants on their way to reunite with their families, to take up a new employment or to study abroad were left stranded. Simultaneously, many migrants were trapped in their destination countries as well as in transit countries, often without an income. The effects on all forms of mobility were especially severe for those who could not rely on a secure shelter or income, and for whom staying home was not possible (such as refugees). All of this is occurring at a time when it has generally become more difficult to migrate, with the exception of highly qualified migrants (King and Okólski 2018).

In 2020, destination countries across Europe and elsewhere suspended immigration processes for asylum seekers, meaning that this group of migrants have been faced with diminished institutional support. The United Nation's migration and refugee agencies as well as resettlement countries, including Switzerland, halted refugee resettlement schemes - a crucial component of expanding legal channels for refugees and of providing a route to international protection - over COVID-19 concerns (IOM 2020). These restrictions left vulnerable forced migrants, 
often living in overcrowded camps and in dense urban areas with high risk of exposure to the virus. Needless to say, that especially in the situation where borders are closed and migrants are trapped in transit countries, unable to reach their destinations, their practical solidarity with families and friends becomes impossible. The refugee crisis already hit those living in vulnerable life conditions the most, and this fact seems to repeat and even be exacerbated during the COVID-19 crisis.

Similar to the refugee crisis, the pandemic brought new societal concerns to the fore and exposed inequalities within and between states. In addition to the precarious situation of refugees, other vulnerabilities, for instance associated with race, are increasingly acknowledged. There is evidence that particular social groups, e.g. ethnic minorities, were disproportionately likely to suffer from the virus in many countries due to their poorer living conditions, longterm health inequalities, and jobs that increase their exposure to the virus, such as in basic services, public transport or logistics (Vertovec 2020b). Furthermore, there is a strong likelihood that in response to lockdowns, industries will accelerate the development of automation capabilities and remove those workplaces that are often operated by migrants. Consequently, according to Yayboke (2020) migrants are at risk to be among those that lose their jobs first.

Another parallel between the two crises - the refugee crisis and the COVID-19 crisis - can be drawn with regards to the reasons for a decrease in solidarity towards vulnerable groups. A study conducted by the Allensbach Institute for Public Opinion Research (2018) found that the proportion of Germans who supported refugees decreased from $50 \%$ during the peak of the refugee crisis in 2015 to just $18 \%$ in 2018 . One explanation for this decrease in solidarity is that the activation push, tied to a concrete emergency - an important justificatory principle driving solidarity in Bhabha's account (2018) - was lower in 2018, years after the peak of the crisis. Other studies have shown that the willingness to practise solidarity towards vulnerable groups declines not only once the emergency is less pertinent but also when individuals realise that there are rule breakers and people taking advantage of a crisis situation (Follmer et al. 2020). The moment when solidarity towards refugees significantly declined in Germany, for instance, was the infamous night of New Year's Eve in Cologne (Follmer et al. 2020). A similar trend can be observed in the present COVID-19 crisis. Compared to March 2020, when the emergency seemed more present for many people, we now observe less public and academic interest in examples of solidarity with vulnerable groups. One possible reason for this is that the predominant focus on the national scale in dealing with the pandemic has led to the assumption that those residing on the same territory are in this crisis together. However, as mentioned earlier, it is becoming increasingly apparent that not everybody is affected by the pandemic in the same way. Different rules apply to the rich and super-rich around the world: while resettlement flights are halted, repatriation flights for the citizens of wealthy nations located in the Global North are guaranteed. Additionally, according to Air Partner, one of the biggest aircraft charter firms, the rich and super-rich continue to travel as much as before, amid reduced flight schedules due to travel restrictions (Neate 2020). The COVID-19 crisis has resulted in a sharp increase in private jet bookings and first-time buyers of business aircrafts. Large aircraft charter firms based in England were overwhelmed with inquiries shortly before the UK-wide lockdowns in March and at the beginning of November 2020 (Neate 2020). Wealthy people around the globe escape the lockdowns and spend their time in their second homes, outside populated cities. The more 
we read of such examples, the more we can expect people to lose their willingness to practise solidarity towards vulnerable groups in crises.

An extended crisis situation is difficult to endure, especially since we live under the illusion of a controllable world. In crisis situations, real or perceived, the world seems more contradictory in general. Therefore, simple solutions to crises, such as neo-nationalism or neo-tribalism - the retreat into the family - can be seen as attempts to regain control. Both successive crises have resulted in an even stronger call, compared to previous years, for exclusive membership and an understanding of democracy as self-determination, in the sense of the right to decide who belongs to the community and control over membership (Song 2018). Such processes of classification mean that some experience a homely privilege of automatic belonging, while others are placed under scrutiny and judged regarding whether they deserve access to the rights of citizenship and welfare entitlements. This discourse of exclusive solidarity intensifies already existing trends in curbing access and entitlement to social welfare of individuals or groups that are not perceived as members of the community (e.g., immigrants) (IOM 2010). Yet, access to health services on the basis of classificatory logics that distinguish between citizens and migrants, between deserving and undeserving citizens - as gradually introduced over the last years by many states - can have devastating consequences during a global pandemic.

In certain cases, the coronavirus crisis even led to increasing waves of xenophobia and populism around the world, such as the xenophobia against Asians in Europe and the US. (e.g., Gamlen 2020; Ren and Feagin 2021; Vertovec 2020a). Nguyen et al. (2020) detect a considerable shift in anti-Asian sentiments in the US with the emergence of COVID-19. Analysing social media data, the authors show that the proportion of negative comments about Asians increased by $68,4 \%$ between November 2019 and March 2020 .

Furthermore, according to Bauböck (2020), the populist tendencies that began in 2015 will intensify despite the fact that fairly open borders and democratic stability go together and that the closure of borders can lead to backslide democracies, populism and the dismantling of democratic rights, like in the case of Hungary or the Brexit. These trends are all but favourable to an atmosphere of solidarity towards migrants, especially if we consider that the good citizen in these pandemic times is the immobile citizen: the one that stays at home.

In sum, once again, we are witnessing a continuation of migration policy trends that have already been introduced during the refugee crisis. These migration measures are certainly not favourable for vitalising migrant solidarity. They limit the financial and time resources - Bhabha's (2018) giving capacity - necessary for an internationally practised solidarity. Without doubts, the current boom of restrictive migration policies, such as the usual restrictions to the entry of low-skilled migrants and asylum seekers as well as the increase in forced return and deportation - legitimised by both crisis discourses - cannot be expected to be over soon. In turn, the transfer of money to poor countries and migrants' ability to engage socially with their home countries continues to decrease.

\section{Discontinuities within continuities: new forms of solidarity?}

During the first Covid wave in spring 2020, while assuming that everyone was equal before the virus, positive voices proclaimed an opportunity for change in existing inequalities and new 
forms of solidarity. Indeed, at that time, the COVID-19 pandemic and the subsequent immobility had created a momentum for consolidating a new sense of community based on local solidarities. In mid-August 2020, Foller et al. published a representative study on the willingness to help vulnerable groups in Germany, in which every third person stated that the pandemic had increased the societal cohesion. Testimonies of solidarity by European citizens for at-risk groups were omnipresent in the daily press, similar to the various solidarity practices of Europeans towards refugees around the peak of the so-called refugee crisis. However, as was the case during the refugee crisis, so far little has been written on solidarity practices of refugees and migrants for at-risk citizens in their countries of residence. An example of such an act of solidarity by refugees is a UNHCR Switzerland project in which Syrian refugees help the elderly Swiss in Geneva to keep safe by doing their grocery shopping (UNHCR 2020). In my opinion, such manifestations of solidarity merit more attention in the mass media. Another concise example of newly emerging forms of sociability can be found in local urban daily interactions, for instance in the US where local joint initiatives of migrants and locals in deprived neighbourhoods are increasingly common, especially in the field of housing. This is due to the fact that many locals are also displaced because of capitalist accumulation and austerity policies (evictions, cuts in benefits, etc.) and because the looming economic crisis is accelerated by the pandemic (Glick Schiller 2020).

Secondly, whilst the pandemic has raised the perception of national borders as symbols of control and safety, it has simultaneously made the interdependency of our economies more visible. Some people have realised that closing the borders risks disrupting the functioning of vital supply chains. The pandemic brought to light that migration is an expression of our interconnectedness, especially if we consider how important cross-border mobility is for migrant workers to carry out the essential work in our societies, as described above. In a globally integrated economy, it has become difficult, if not impossible, to simply halt international movement. Moreover, many citizens who live outside their countries might also have realised that the restrictions of movements for migrants might as well influence their own mobility and settlement rights abroad. In Bridget Andersons' (2019: 11) words: "Mobility and international migration are indications of our inter-dependence, the challenge is how to make these interdependencies visible. Perhaps we can start from the insight that what is bad for migrants is not good for citizens, indeed, it is often bad for citizens as well". Having said that, the question arises: Is the global pandemic a chance to move away from the dominant public perceptions of migration as a problem towards perceiving migration as a social fact - the normality and not the exception in human history? Will the pandemic present an opportunity to shift discussions surrounding migration away from the predominant negative stance to an emphasis on more positive aspects, such as balancing out the aging population or the just-described interdependencies?

Thirdly, the pandemic has also inverted previous hierarchies and categories of more or less desired migrant workers and the solidarity that is shown towards them. As mentioned earlier, European migration policies ease the movement for selected high-skilled migrants, such as engineers or managers, and seek to prevent the movement of others - particularly low-skilled migrants from the Global South (King and Okólski 2018). High-skilled migrants, who have been in high demand in many wealthy countries for years, have been left somewhat stranded in their 
home countries due to travel restrictions and recruitment stops. By contrast, the so-called lowskilled migrants, habitually underpaid in their occupations and typically made the scapegoats in the public anti-immigration discourses in their host countries, are nowadays recognised as essential for the system. In 2020, special arrangements (e.g. charter flights or housing arrangements) for workers in food processing plants and for carers across Europe were implemented to guarantee they could fulfil their roles as relevant providers of services (Vertovec 2020b). In Canada, Italy and Portugal, undocumented carers and farm workers have benefited from newly introduced regularisation programmes or from new long-term statuses, as in the case of the Canadian Agri-Food immigration pilot, implemented on 15 May 2020. Additionally, the recognition of diplomas of refugees by the British national health service, a hotly disputed topic for years, suddenly became possible (Vertovec 2020a). These examples illustrate that migration measures considered unrealisable until very recently are now indeed possible - a discontinuity in the continuity of ever-increasing restrictive migration measures across the crises. This turn in migration policies, I argue, is favourable for low-skilled migrants because of more stable employments, higher salaries and secure residence conditions that allows them to travel back and forth between their countries of residence and their home country, among other things. Consequently, this trend also has a positive impact on the low-skilled migrants' cross-border solidarity actions towards their home countries and families, so far neglected in the overall policy discourse. Extra financial resources and the possibility for migrants to travel to their home countries are important factors that positively affect these migrants' ability to support communities and families abroad. In this light, does the crisis present an opportunity to improve our immigration regimes towards more humane and equitable policies? Or are we going to experience an objectification rather than a humanisation of those who continue to provide necessary services?

Lastly, on the individual level, many have experienced a suspension of time due to the conditions of lockdown that consisted of delays, waiting, persisting. Many have got a taste of what it means when the state governs their time and their rights to move. These experiences of living in limbo are extraordinary for most of us. Yet, they are all too familiar for many international migrant workers and asylum seekers. Their living conditions are often marked by experiences of permanent temporariness based on immigration laws that cause insecurity and instability, i.e., long periods of uncertainty and suspension of settlement and citizenship rights (Anderson 2019). In short, migrants often experience what is called asylum seeker time, a temporariness that extends for an unknown period and over which people have limited control (see, e.g., Cohen 2018). In this light, will these new personal experiences of permanent temporariness and unsettlement result in more solidarity and compassion towards migrants and to a greater understanding of some of their living conditions in the future?

On a positive note, we can conclude that the present immobility caused by the pandemic has influenced narratives that render existing inequalities more visible. For instance, more attention has been paid to the precarious living and working conditions of refugees and seasonal workers. Additionally, some have engaged in activities they never considered before, such as volunteering. Hence, in a world in which the old structures do not hold (Glick Schiller 2020), the present immobility unlocks a potential for what could be in the future. 


\section{Conclusion and Discussion}

Times of crisis always create individual and social vulnerabilities. As discussed in this article, migrants with few qualifications and resources embody the tensions of freedom of movement and the immobilisation during the pandemic the most. They are predisposed to be among the first to be affected by restrictive mobility measures. This particularly endangers the lives of vulnerable populations for whom movement is a means of survival. Overall, the refugee crisis and the COVID-19 crisis have brought to the fore the manifold ambivalent meanings of mobility to which it is crucial to pay more attention in the future. Both crises show in an illustrative way that (im-)mobilities are shaped by different inequalities that significantly impact on who has access to mobility. Yet, the crises also draw attention to the groups that are able to lead an immobile lifestyle, understood as a personal experience of stability that allows individuals to create stable support networks in precarious life situations caused by crises.

As Hariri (2020:5) points out with regards to temporary measures implemented in times of crises: "Temporary measures have a nasty habit of outlasting emergencies". As argued throughout this article, previous restrictive migration policies implemented during the so-called refugee crisis, for instance the restrictions to the entry of asylum seekers, have survived the refugee crisis and regained legitimacy in the current pandemic. Both crisis discourses do not only legitimise migration politics of fear, they also continue to obstruct the ability of migrants to support their families and friends back home by means of transnational solidarity practices. As illustrated in the first section of this article, migrants' commitment to solidarity during both crises has not always been fully taken into account by academics and policy makers in the Global North.

COVID-19 has ushered in a new era of migration restrictions, and while these regulations are designed to be temporary, it is not hard to imagine that some leaders around the globe will manufacture crisis discourse after crisis discourse to keep the borders of their countries de facto closed to migrants. Hence, the opportunity that has been missed during the refugee crisis will become a necessity post COVID-19, namely to call for a reversal of these policies once the crisis is over. This will be crucial to prevent a new regime of unfreedom of movement in Europe and beyond (Favell and Recci 2020: 5). As Shachar (2020: 6), referring to the amplified border control systems and surveillance introduced in the year 2020, points out: "While extraordinary measures such as restrictive mobility appear to be the necessary call of the hour, when the day comes that we defeat this deadly virus we will need to proactively undo the draconian surveillance and control measures that this virus has unleashed without hesitation".

Further challenges loom on the horizon with regards to migration policies in this new era of immobility. Thus far, as stated above, migration regimes have become increasingly selective, prioritising those who can productively contribute to the economies of developed countries, while certain forms of migration from developing countries continue to be condemned, such as the less educated and those portrayed as a liability to the host countries, even though they are the ones who have been carrying out essential low-paid work (Watkins 2020). Yet, the migration pressure towards the Global North will most likely persist due to various factors such as the demographic development on the African continent, among others (King and Okólski 2018). Additionally, there is a strong probability that this pressure will be amplified by an increase in individuals whose livelihoods have been aggravated because of a loss of income due to 
the pandemic. Hence, more people will seek better economic opportunities in the future due to potential economic regressions or for higher quality of health facilities.

For all of these reasons, global collective approaches to migration policy making during and after the COVID-19 era are necessary. The COVID-19 crisis and migration are global phenomena that require global cooperation and transnational solidarity rather than nationalist isolationism and protectionism. In order to combat the spread of the virus, global and concerted solidarity in terms of vaccination programmes is essential. Moreover, a global response to migration would imply moving away from the narrow binary categorisation of desirable and undesirable migrants, which sustains the idea of migration as a crisis in itself and maintains the public illusions that migration can under all circumstances be managed and that our societies are self-sufficient. As I have presented, the scale and implementation of tens of thousands of travel restrictions and COVID-19-related containment measures require states to work with their neighbours. That invites further reflections on how we can create new spaces and forms of solidarity in times of crisis, for migrants and non-migrants alike.

The social sciences, due to their history and practice, are particularly well prepared to contribute to a better understanding of the challenges imposed by these crises on the dynamics of our society and its underlying types of solidarity (Salazar 2020). Social science scholars can contribute to preventing solidarity from becoming an empty signifier, analogous to the concept of hospitality which according to DeBono (2019) turned into a plastic word due to its loss of actual meaning through inflationary use. As regards avenues for further research on the interlinkages between the social dynamics of (im-)mobility and solidarity and for unpacking the social, cultural, economic and political consequences of today's immobility and distance in daily life, research on transnationalism should be another valuable source. Furthermore, one of the most pressing tasks of research on solidarity and mobility in the present times of crisis is to refine the analytical tools necessary to understand the complex interplays between forms of connectivity and forms of mobility. It would be worth exploring, for instance, if transnational practices, including transnational solidarity practices, aggravate or ameliorate experiences of involuntary mobility; thus, whether they can create a social co-presence with physical absence or whether connectivity in all its forms will one day even replace mobility. As this outline of cross-border solidarity practices among migrants has illustrated, studies on transnationalism can help examining the interplay of connectivity and social embeddedness that underlies the present situation. Finally, a transnational approach also takes into account the so far mostly neglected effects of the crisis on migrant-sending countries and their needs and uncertainties.

Either way and as paradox as it might seem, the present crisis of immobility can be understood as a starting point for an increasingly interconnected approach to both mobility and solidarity as avenues for further reflections on forms of connectivity that do not only refer to transnational linkages between nation states but also to the interdependencies between citizens and migrants. Only time will tell whether after the COVID-19 crisis the habitual, normal ways of understanding solidarities and mobilities will return or whether the crisis triggers a path towards a future with new forms of solidarities (re)imagined during the lockdown. 


\section{Acknowledgements}

I am grateful to the anonymous reviewers and the editors of socialpolicy.ch for helpful comments and feedback.

\section{Declaration of conflicting interests}

The author declared no potential conflicts of interest with respect to the research, authorship, and/or publication of this article.

\section{Funding}

The author did not receive any financial support for the research, authorship, and/or publication of this article.

\section{References}

Agustín, O.C. and Jørgensen, M. (2020). On Transversal Solidarity: An Approach to Migration and Multi-Scalar Solidarities. Critical Sociology, Online first, 1-17. Last accessed 31.03.2021 on https://journals.sagepub.com/doi/pdf/10.1177/0896920520980053.

Allensbach, Institut für Demoskopie (2018). Engagement in der Flüchtlingshilfe. Ergebnisbericht einer Untersuchung des Instituts für Demoskopie Allensbach. Berlin: Bundesministerium für Familie, Senioren, Frauen und Jugend.

Anderson, B. (2019). New Directions in Migration Studies: Towards Methodological Denationalism. Comparative Migration Studies 7(1): 1-13.

Bansak K., Hainmueller J., Hangartner D. (2016). How economic, humanitarian, and religious concerns shape European attitudes toward asylum seekers. Science 354: 217-222.

Barber, P. (2011). A Curious Colony - Leicester Square and the Swiss. London: Jannuzzi Smith Editions.

Bauböck, R. (2020). The Democratic Case for Immigration in the European Union, talk held at the European University Institut, Florence. Last accessed 26.01.2021 on https://www.eui.eu/events/detail? eventid=169436.

Beck, S. (2011). Migranten und Engagement: Die Milieuperspektive. Soziale Bewegungen, 24 (2): 24-37. Last accessed 06.02.2021 on http://forschungsjournal.de/sites/default/files/archiv/fjsb_2011_2.pdf.

Bhabha, J. (2018). Can we solve the Migration Crisis? Polity Press, Cambridge: 31-59.

Carling, J. (2015). Refugees are also Migrants. All Migrants Matter. Last accessed 23.01.2021 on http://bordercriminologies.law.ox.ac.uk/refugees-are-also-migrants.

Ciobanu, R. O. (2020). Familien und Unterstützung aus der Ferne. In: Gamba, F. Nardone, M. Riccardi, T. and Cattacin, S. (eds.) COVID-19. Eine sozialwissenschaftliche Perspektive. Zurich and Geneva: Seismo: 141-156. 
Collyer, M. and King, R. (2016). Narrating Europe's migration and refugee 'crisis'. Human Geography, 9 (2): 1-12.

Cohen, E. F. (2018). The political value of time: Citizenship, duration, and democratic justice. Cambridge: Cambridge University Press.

Crawley, H. (2016). Managing the Unmanageable? Understanding Europe's Response to the Migration 'Crisis', Human Geography, 9 (2): 16-22.

Crow, G. (2001). Social solidarities: theories, identities and social change. Buckingham: Open University Press.

DeBono, D. (2019). Plastic hospitality: The empty signifier at the EU's Mediterranean border. Migration Studies, No. 1: 1-22.

Favell, A. and Recci, E. (2020). Mobilities, neo-nationalism and the lockdown of Europe: will the European Union survive? COMPAS Centre on Migration Policy \& Society, Corona and Mobility Forum, Oxford: University of Oxford. Last accessed 22.12.2020 on https://www.compas.ox.ac.uk/2020/mobilities-and-the-lockdown-of-europe-will-the-european-union-survive/.

Follmer, R., Brand, T. and Unzicker, K. (2020). Gesellschaftlicher Zusammenhalt in Deutschland: Eine Herausforderung für alle. Ergebnisse einer repräsentativen Bevölkerungsstudie. Gütersloh: Bertelsmann Stiftung. Last accessed 18.02.2021 on https://www.bertelsmann-stiftung.de/de/publikationen/publikation/did/gesellschaftlicher-zusammenhalt-in-deutschland-2020.

Gamlen, A. (2020). Migration and Mobility after the 2020 Pandemic: The End of an Age. University of Oxford's Centre on Migration, Policy and Society (COMPAS). Last accessed 29.03.2021 on https://www.compas.ox.ac.uk/2020/migration-and-mobility-after-the-2020-pandemic-the-endof-an-age- $2 /$.

GIZ (Deutsche Gesellschaft für Internationale Zusammenarbeit) (2019). Migration for Development Programme. Last accessed 06.02.2021 on https://www.giz.de/en/worldwide/62318.html.

Glick Schiller, N. (2020). Theorising changing conditions and ongoing silences. In: Bastia, T. and Skeldon, R. (eds.) Routledge Handbook of Migration and Development. London and New York: Routledge: 32-41.

Hager A., Veit S. (2019). Attitudes towards asylum-seekers: evidence from Germany, Public Opinion Quarterly 83(2): 412-422.

Hariri, Yuval (2020). The world after coronavirus. Financial Times, March 22 2020. Last accessed 29.01.2021 on https://www.ft.com/content/19d90308-6858-11ea-a3c9-1fe6fedcca75.

Huth, S. (2012). Freiwilliges und bürgerschaftliches Engagement von Menschen mit Migrationshintergrund - Barrieren und Türöffner, Wiso direkt: Analysen und Konzepte für die Wirtschafts- und Sozialpolitik. Bonn: Friedrich Ebert Stiftung. Last accessed 17.02.2021 on https://library.fes.de/pdffiles/wiso/09497.pdf.

IOM (International Organisation for Migration) (2010). World Migration Report 2010. The future of migration: building capacities for change. Geneva: IOM.

IOM (International Organisation for Migration) (2020). COVID-19, Diseases Responses, Situation Report, No. 16. Last accessed 15.02.2021 on https://www.iom.int/sites/default/files/situation reports/file/iom COVID-19 sitrep16 16-22may2020.pdf. 
IOM (International Organisation for Migration) and Migration Policy Institute (MPI) (2012). Developing a Road Map for Engaging Diasporas in Development: A handbook for Policymakers and Practitioners in Home and Host Countries. Geneva: IOM.

Karakayali, S. and Kleist, O.J. (2016). Volunteers and asylum-seekers, Forced Migration Review, No. 51: 63-67.

King, R. and Okólski, M. (2018). Diverse, Fragile and Fragmented: The New Map of European Migration, Central and Eastern European Migration Review, 2: 1-24.

Levitt, P. (1998). Social remittances: migration driven local-level forms of cultural diffusion. International Migration Review, 34, 926-948.

Neate, R. (2020). Private jet bookings soar as wealthy flee second England lockdown. The Guardian, November 3 2020. Last accessed 19.02.2021 on https://www.theguardian.com/business/2020/nov/03/private-jet-bookings-soar-as-wealthy-flee-second-england-lockdown.

NZZ (Neue Zürcher Zeitung) (2019). Entwicklungspolitik ist, wenn die Hilfe bei den Helfern bleibt, September 1 2019. Last accessed 16.02.2021 on https://www.nzz.ch/wirtschaft/entwicklungspolitikwenn-die-hilfe-bei-den-helfern-bleibt-ld.1504626?reduced=true.

Nguyen T.T., Criss S., Dwivedi P., Huang D., Keralis J., Hsu E., Phan L., Nguyen L.H., Yardi I., Glymour M.M., Allen A.M., Chae D.H., Gee G.C., and Nguyen Q.C. (2020). Exploring U.S. Shifts in AntiAsian Sentiment with the Emergence of COVID-19, International Journal of Environmental Research and Public Health, 17(19).

Odermatt, E. (2021). We do Solidarity not Charity - Transnational Development Practices of Moldovan Migrants and Temporalities. In: Meyer, S. (ed.) More than Money: Remittances as Social Practice. Basingstoke: Palgrave Macmillan: XX-XX (forthcoming, August 2021).

Odermatt, E. (2017). Migrants in Development: A Multi-Perspective Analysis of the Participation of Moldovan Migrant Associations in Development Initiatives. Doctoral thesis (PhD). University of Sussex. Last accessed 29.01.2021 on http://sro.sussex.ac.uk/id/eprint/68110/.

Page, B. and Mercer, C. (2012). Why do people do stuff? Reconceptualising remittance behaviour in diaspora-development research and policy. Progress in Development Studies, 12 (1), 1-18.

Ratha, D., Mohapatra, S. and Silwal, A. (2009). Migration and remittance trends 2009, Development Brief 11, Migration and Remittances, Team Development Prospects Group, Last accessed 12.02.2021 on http://pubdocs.worldbank.org/en/468711444756850486/MigrationAndDevelopmentBrief11.pdf.

Ren J. and Feagin J. (2021). Face mask symbolism in anti-Asian hate crimes, Ethnic and Racial Studies, 44:5: 746-758.

Salazar, N. B. (2020). Anthropology and Anthropologists in Times of Crisis, Social Anthropology 28 (2): 346.47 .

Shachar, A. (2020). Borders in the Time of COVID-19. Ethics \& International Affairs (EIA)/ Carnegie Council, Cambridge University Press. Last accessed 22.01.2021 on: https://www.ethicsandinternationalaffairs.org/2020/borders-in-the-time-of-COVID-19/.

Sigona, N. (2017). NGOs Under Attack for Saving too Many Lives in the Mediterranean, The Conversation, March 29 2017. Last accessed 13.02.2021 on https://theconversation.com/ngos-under-attackfor- saving-too-many-lives-in-the-mediterranean-75086.

Song, S. (2018). Immigration and Democracy. Oxford: Oxford Political Theory. 
Stadelmann-Steffen, I. (2015). Freiwilligen-Monitor Schweiz 2014. Zürich, Seismo-Verlag.

SEM (State Secretariat for Migration) (2019). Bericht Monitoring Sozialhilfestopp: Berichtsperiode 2019. Last accessed 10.01.2021 on https://www.sem.admin.ch/sem/de/home/publiservice/berichte/monitoring sozialhilfestopp.html.

UN DESA (United Nations Department of Economic and Social Affairs, Population Division) (2020). International Migration 2020. New York: United Nations Publication.

UNHCR (United Nations Refugee Agency) (2020). Syrian Refugees Aid Vulnerable Swiss Amid COVID19 Outbreak. Last accessed 12.02.2021 on https://www.unhcr.org/news/stories/2020/3/5e7878d94/syrian-refugees-aid-vulnerable-swiss-amid-COVID-19-outbreak.html.

Van Dyk, S. and Misbach E. (2016). Zur politischen Ökonomie des Helfens. Flüchtlingspolitik und Engagement im flexiblen Kapitalismus, PROKLA, 183, No. 2: 205-227.

Vari-Lavoisier, I. (2020). Social Remittances. In: Bastia, T. and Skeldon, R. (Eds.), Routledge Handbook of Migration and Development. London and New York: Routledge, 125-136.

Vertovec, S. (2020a). COVID-19 and Enduring Stigma. The Corona Pandemic Increases Xenophobia and Exclusion Worldwide. Göttingen: Max Planck Institute for the Study of Religious and Ethnic Diversity. Last accessed 29.01.2021 on https://www.mpg.de/14741776/COVID-19-and-enduringstigma.

Vertovec, S. (2020b). Global Migration and the "Great Reshaping". Göttingen: Max Planck Research 3, Last accessed 29.01.2021 on https://www.mpg.de/16261304/W001 Viewpoint 020-025.pdf.

Watkins, J. (2020). Irregular Migration, Borders, and the Moral Geographies of Migration Management, Environment and Planning C., 38(6): 1108-1127.

World Bank (2020). Personal remittances, received (\% of GDP). Last accessed 29.01.2021 on https://data.worldbank.org/indicator/BX.TRF.PWKR.DT.GD.ZS.

Yayboke, E. (2020). Five Ways COVID-19 Is Changing Global Migration. Washingon D.C: Centre for Strategic and International Studies. Last accessed 28.01.2021 on https://www.csis.org/analysis/fiveways-COVID-19-changing-global-migration. 